\title{
Impact of Variation Orders on Time and Cost in Mega Hydropower Projects of Pakistan
}

\author{
Hashim Hanif1, Muhammad Bilal Khurshid', *Søren Munch Lindhard² and \\ Zuhaib Aslam³
}

Published online: 21 December 2016

To cite this article: Hashim Hanif, Muhammad Bilal Khurshid, Søren Munch Lindhard and Zuhaib Aslam. (2016). Impact of variation orders on time and cost in mega hydropower projects of Pakistan. Journal of Construction in Developing Countries, 21 (2): 37-53. https://dx.doi.org/10.21315/jcdc2016.21.2.3

To link to this article: $\mathrm{https} / / / \mathrm{dx} . \mathrm{doi} . \mathrm{org} / 10.21315 / \mathrm{jcdc} 2016.21 .2 .3$

Abstract: The occurrence of variation orders (VOs) in the construction industry is a regular trend all over the world. Hydropower projects are no exception, and it is difficult to find a hydropower project in Pakistan that does not experience VOs. The current research investigates the causes and impacts of VOs in mega hydropower projects using case studies of three mega hydropower projects in Pakistan. The results illustrate that errors and omissions in design, changes in scope and changes in design were among the three top contributing factors to VOs in hydropower projects that resulted in time and cost overruns. Because of VOs, the time overrun is $20 \%$, and the cost overrun is $31 \%$ with respect to the planned time and cost of the project. Based on this research, the study recommends measures to curb the causes and impacts of VOs to optimise the construction process of mega hydropower projects.

Keywords: Mega hydropower projects, Variation order (VO), Time overrun, Cost overrun, Pakistan

\section{INTRODUCTION}

A variation order (VO) is any change or modification to the design, quality or scope of work that is subject to an agreement with respect to the volume or nature of work carried out (O'Brien, 1998). The construction industry's complex processes are prone to inevitable changes. To respond to these changes, change orders are issued to modify the original scope or design of the construction project (Construction Industry Institute [CII], 1990).

VOs ultimately lead to delays in project completion (Arain, Assaf and Low, 2004). Delays increase the cost of construction because of price adjustment and fluctuations in the prices of various components, i.e., labour, fuel, cement and miscellaneous materials. In Pakistan, cost overrun also leads to serious problems in upcoming projects due to limited funds being available because most hydropower projects are funded by the World Bank and Asian Development Bank (ADB) on a loan basis.

\footnotetext{
'Military College of Engineering, National University of Sciences and Technology (NUST), Risalpur Campus, KPK, Pakistan

2Barslund A/S, DENMARK

${ }^{3}$ COMSATS, Virtual Campus, Institute of Information Technology, PAKISTAN

*Corresponding author: lindhard@gmail.com

(C) Penerbit Universiti Sains Malaysia, 2016
} 
Whenever a project is delayed, it is difficult to agree on the additional time and the costs associated with such a delay. Disputes and claims arise when neither party (employer and contractor) agrees on the extra time and cost. This study's results are beneficial for the employer, contractor and even the general public by allowing an understanding of the causes and effects of VOs in the construction of hydropower projects in Pakistan.

In the 1970s, the Chartered Building Institute of the UK investigated VOs, especially their causes and effects, and found that time delays and cost overrun increase as a result of variations to construction contracts, as explained by Goodacre and Hunter (1990). In 1990, the Construction Industry Institute (CII) of the USA established two task teams focused on time and cost to examine the root causes, impact and magnitude of changes and how these changes can be managed effectively (Cll, 1990). In addition to these institutes' efforts, numerous research studies have considered various construction projects, as discussed below.

\section{LITERATURE REVIEW}

Changes and variations are, regardless of source, undesirable but remain common in all types of construction projects (O'Brien, 1998; Frisk, 1997). They are undesirable because of their negative effects on either the production flow or the product, which result in decreases in cost, time and quality performance (González et al., 2010; Lindhard, 2014).

VOs are among the main causes of changes and variation in construction (Al-Momani, 2000). Therefore, VOs have a substantial effect on a project's cost and time performance (lbbs, 1997).

The many different parties that are involved in a construction project result in a high possibility for VOs to arise. Thus, VOs can be caused by the consultant, the employer, or the contractor (Hanna, Calmic and Peterson, 2002). Therefore, VOs are common and are considered a normal part of a construction project (Arain and Low, 2005).

A degree of change should be expected because it is difficult for clients to visualise the end product that they procure (Love, 2002). Variations occur more frequently when renovating or upgrading a construction. Arain and Low (2005) found that the average number of variations in upgrading projects was almost $21 \%$ more than that in new projects.

Summed up, "the success of a construction project to a large extent is determined by the ability of the project team to manage the inevitable changes during the project" (Sun and Meng, 2009). The project team must make the necessary precautions to minimise both the number of VOs and their induced negative effect.

Previous studies have focused on the causes of VOs. For instance, Alnuaimi et al. (2010) explored the causes of VOs in construction projects in Oman and found the top three reasons of VOs to be related to (1) additional work instructed by owner, (2) modifications by owners and (3) non-availability of manuals and specifications. Muhammad et al. (2010) looked into the causes of VOs in construction projects of Malaysia and found that the top three reasons of VOs were (1) change in plans by owner, (2) substitution of materials and (3) change in 
design by consultant. Additionally, in a study in Iran, Ismail et al. (2012) identified the top three reasons of VOs to be (1) change of plans, (2) errors and omissions in design and (3) differing site conditions. Finally, Hanif et al. (2014) analysed VOs in hydropower projects of Pakistan and found the top three reasons to be (1) change in scope, (2) omissions in design and (3) change in design.

Project performance depends on a well-structured schedule. If the work is carried out smoothly within the time limits and approved budget, then maximum project performance is achieved. VOs induce project changes that have negative effects on project performance (Ismail et al., 2012). Variations adversely impact project performance in terms of cost, time delays, poor quality, productivity degradation, health and safety issues and professional relations among the parties to the contract (Al-Jishi and Al-Marzoug, 2008; Enshassi, Arain and Al-Raee, 2010).

Many construction projects incur increased costs because of variation; however, all variations do not increase costs. Deletion in most cases reduces the overall cost of the project, while additions always increase costs (Thomas et al. 2002). The following direct costs are associated with VOs (Ssegawa et al. 2002):

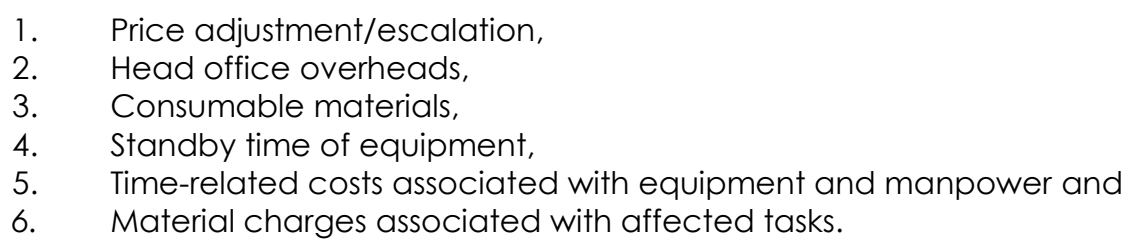

The employer always requires that their project be completed within the prescribed time because the costs associated with additional time are greater than the employer can bear. The contractor likewise desires to complete the project according to or within the allotted time. If the project is completed ahead of time, the contractor is typically awarded with a bonus and if the project is delayed because of an event for which the contractor is responsible, then the contractor is penalised with a contract-specific but often unbearable amount of liquidated damages. VOs are among the key reasons for project time and cost overruns (Bower, 2000).

A number of studies have also explored the effects of VOs in construction. Alnuaimi et al. (2010) found in a study in Oman that the top three effects of VOs were (1) delays, (2) claims and disputes and (3) cost overruns. Moreover, ljaola and lyagba (2012) studied VOs in Nigeria and found the top three effects of VOs to be (1) claims and disputes, (2) delays and (3) cost overruns. In a research study carried out in Pakistan, Haseeb et al. (2011) found VOs to be the most frequent reason for delays. Another study in Denmark by Lindhard and Wandahl (2014) identified changes in work plans as the second most important cause of delay.

\section{Scientific Contributions}

The causes of variations and their effects/impacts have been explained by numerous authors, and many related papers have been published in all recognised journals from 1990 to date. Research on VOs has been carried out in many countries, such as the USA, the UK, South Africa, Iran, Malaysia, Oman, 
Hashim Hanif et al.

Jordan, Nigeria and Taiwan, particularly considering multi story buildings, institutional buildings and highway projects. However, the previous research has not emphasised the impact that VOs have on the construction of hydropower projects. To the best of our knowledge, no research has been carried out in Pakistan to identify the causes of variations in hydropower projects. The present research thus fills this knowledge gap by reviewing the existing literature on construction projects and investigating the causes and impacts of VOs in hydropower projects in Pakistan. Further, it offers recommendations for minimising the effect of VOs in such projects.

\section{Scope of Study}

The study is limited to the construction of hydropower projects (projects costing over 5000 million rupees) executed by the Federal Government of Pakistan over the last 10 years. These projects are constructed by construction contractors of the category C-A, as classified by the Pakistan Engineering Council. Grade C-A contractors have no limit for the construction cost of projects.

\section{Pakistani Environment}

It is imperative to understand Pakistan's climatic conditions and environment before seeking to identify the factors that cause VOs in hydropower projects. Most of Pakistan's hydropower projects are located in the north of the country, which has a period of cold weather and snowfall for almost three months during the winter season. The temperature in the winter can fall below $-10^{\circ} \mathrm{C}$ in certain areas. Because it is difficult to work on site in these extreme conditions, most contractors prefer to work in the summer.

These extreme climatic conditions pose various problems to contractors, including difficult delivery of equipment in high altitudes and unavailability of skilled manpower. Extreme weather disrupts the progress of work and delays projects, thus causing cost and time overruns. To respond to the problems posed by extreme weather and limited time available for work, a number of VOs are issued that adversely impact the progress of work. Understanding the causes of variations and their impacts can allow the effective control of these variations.

Hanif et al. (2014) ranked the causes of VOs in Pakistan using the relative importance index, shown in Table 1. 
Table 1. Factors Causing VOs

\begin{tabular}{lcc}
\hline \multirow{2}{*}{ Factors Causing vos } & \multicolumn{2}{c}{ Overall } \\
\cline { 2 - 3 } & RII & Rank \\
\hline Scope changes by employer & 0.83 & 1 \\
Omissions and mistakes in design & 0.82 & 2 \\
Design changes & 0.82 & 3 \\
Change of project schedule & 0.76 & 4 \\
Discrepancies between contract documents & 0.75 & 5 \\
Inadequate project objectives & 0.75 & 6 \\
Owner's financial problems & 0.7 & 7 \\
Inadequate shop drawing details & 0.70 & 8 \\
Design complexity & 0.69 & 9 \\
Unavailability of equipment & 0.68 & 10 \\
Change in specification by owner & 0.68 & 11 \\
Substitution of materials by employer & 0.67 & 12 \\
Insufficient scope of work for contractor & 0.67 & 13 \\
Consultant's lack of knowledge on available materials & 0.65 & 14 \\
Change in government regulations & 0.65 & 15 \\
Unforeseen problems & 0.62 & 16 \\
Contractor's lack of involvement in design & 0.62 & 17 \\
Inaccessibility of skilled manpower & 0.60 & 18 \\
Contractor's financial difficulties & 0.56 & 19 \\
Defects in works executed & 0.50 & 20 \\
\hline
\end{tabular}

Source: Hanif et al. (2014)

\section{RESEARCH METHOD}

The presented research is based on the 38 causes of VOs identified in a literature review by Hanif et al. (2014). By applying a questionnaire to employers, consultants and contractors from hydropower projects in Pakistan, Hanif et al. (2014) ranked the VOs by relative importance. To verify the results, they tested the findings using a reliability test (Cronbach alpha). All scales were found to be in the acceptable range, with alpha values above 0.70, as defined by Nunnally (1978).

Building on Hanif et al. (2014), this research uses case studies to make an indepth analysis of the causes and impacts of VOs on the time and cost of selected hydropower projects in Pakistan. By comparing our findings to those of Hanif et al. (2014), a number of recommendations are presented. The research process is shown in Figure 1. 


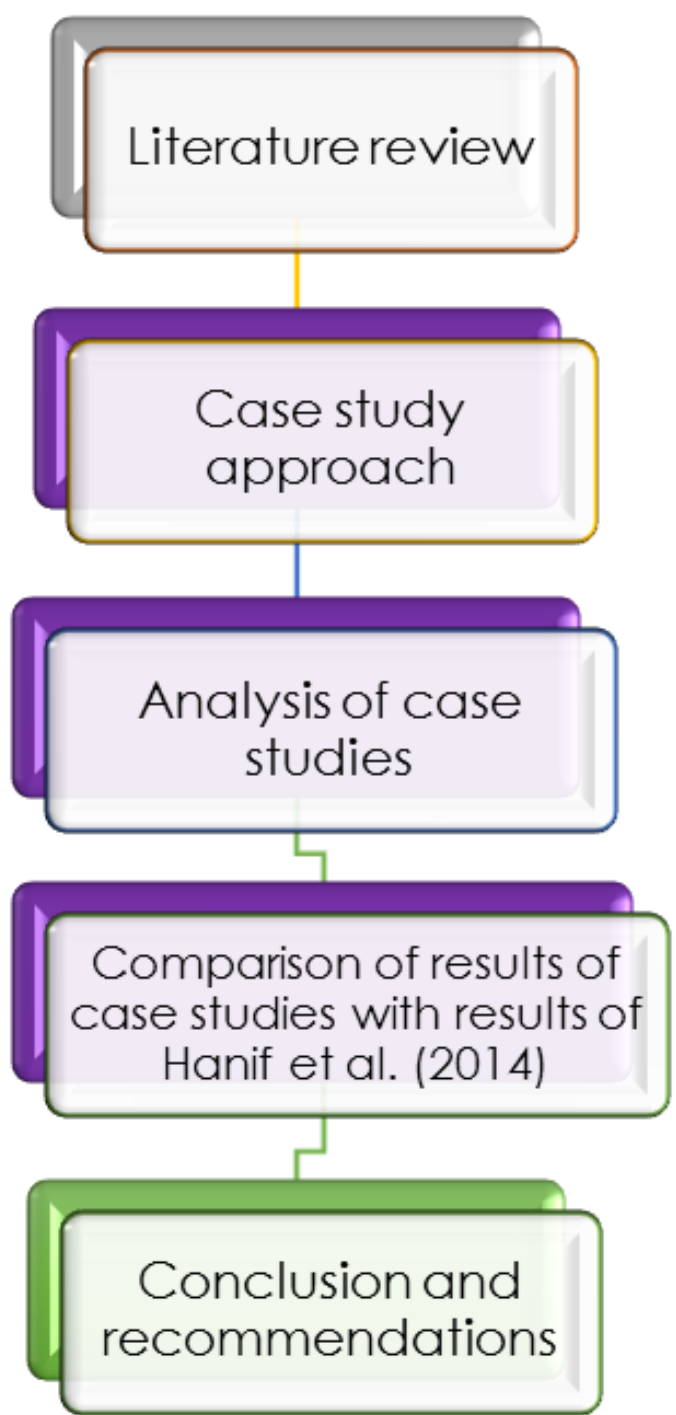

Figure 1. Research Methodology Flow Chart

A qualitative case study approach was applied to three hydropower projects because this approach allows the object studied to be viewed in its context (Yin, 2003) and thus offers a deeper understanding of causes and impacts of $\mathrm{VO}$. The methods of data collection in all three cases consist of the following:

1. Interviewing the relevant persons involved in the construction of the hydropower plants.

2. Reviewing archived project documents. 
The analysis was carried out by examining and taking notes on the monthly progress reports, design reports, project completion reports, correspondence among client, consultant and contractor and various meetings recorded in the form of minutes, all of which indicated the causes and effects/impacts of VOs on projects.

\section{CASE STUDY FINDINGS}

This section presents a summary of VO analysis based on case studies of the three selected mega hydropower projects in Pakistan, each with different capacities, that were executed by the Government of Pakistan. Unit/item rate, which is the traditional method, was used as delivery system for all of the projects. In this method, the client hires a consultant for the project design, and a contractor is selected by bidding. Table 2 shows the salient features of each mega hydropower project studied.

Table 2. Salient Features of Three Case Studies

\begin{tabular}{lccc}
\hline & Case I & Case II & Case III \\
\hline Type of contract & Unit Rate & Unit Rate & Unit Rate \\
Size of facility (MW) & 1,450 & 1,000 & 969 \\
Total no. of VOs issued & 46 & 43 & 38 \\
Contract duration (days) & 1,555 & 1,178 & 2,830 \\
Contract cost (million USD) & 266 & 229 & 1,515 \\
\hline
\end{tabular}

\section{Case Study No. 1: Hydropower Project, 1450 MW}

Case Study No. 1 is the Ghazi Barotha Hydropower Project, located on the Indus River, $7 \mathrm{~km}$ downstream of Tarbela Dam, in Khyber Pakhtoonkhowa province. The project was completed during the fiscal year 2003-2004. The dam is placed at a major run of the river and is an environmentally sustainable project designed to meet the acute shortage of peak power demand in the country. The project is based on the utilisation of the hydraulic head available between the tailrace at Tarbela Dam and the confluence of the Indus and Haro Rivers for power generation. In this reach, the Indus River drops by $76 \mathrm{~m}$ in a distance of $63 \mathrm{~km}$ and generates 1,450 MW electricity and 6.6 billion units kilowatt-hours annually. The start and end dates of the projects were December 1995 and August 2003, respectively. The project's 46 VOs delayed project completion by 200 days, and the four VOs selected for study had a collective time impact of 90 days, which indicates an impact of $45 \%$ of the project's total delay. This significant time impact was the main reason for selecting these VOs for the study. The pictorial view of the project is shown in Figure 2. 


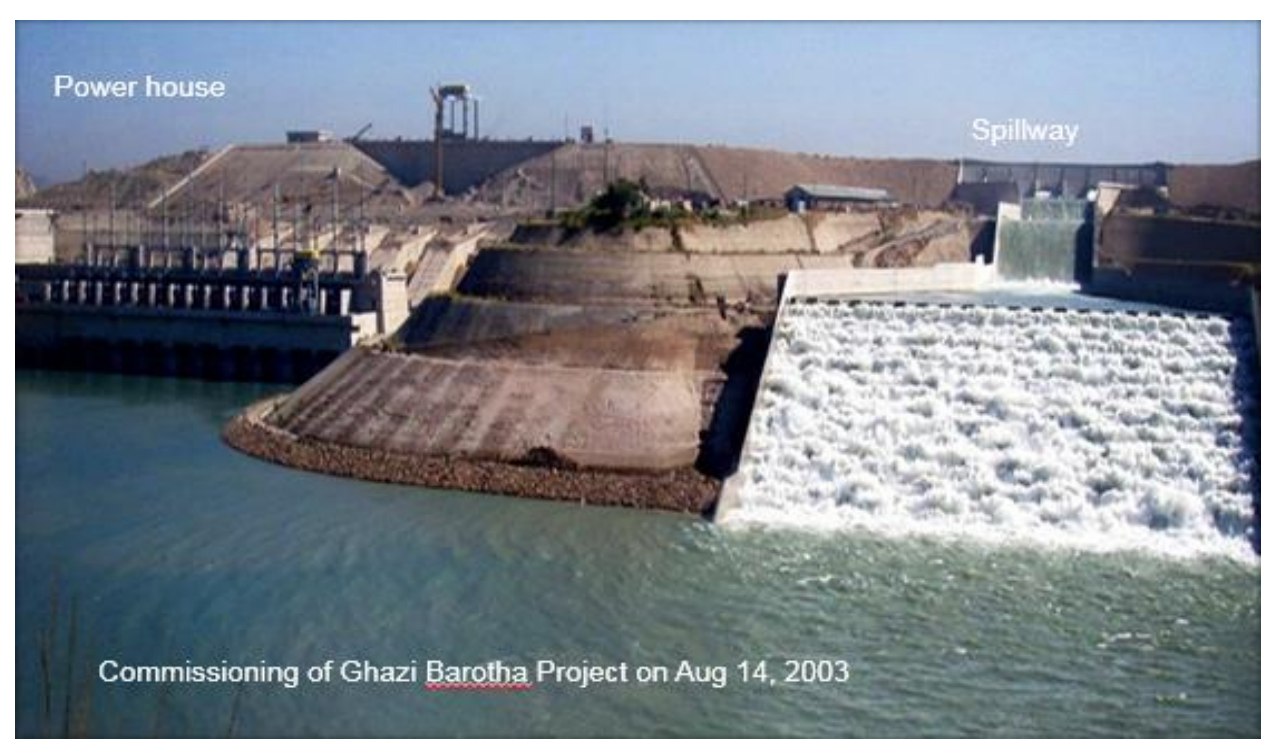

Figure 2. Ghazi Barotha Hydropower Project (1450 MW)

During the construction phase of this project, a number of VOs were issued by the consultants. The descriptions of the four major VOs are as follows:

1. VO No. 1, Change in Design: It was issued to flatten the slopes above service road level. In tender, the drawn slopes were very steep; this was changed to a mild slope during design review to safeguard the service road against falling material. As a result of this $\mathrm{VO}$, the additional cost to the project was USD 0.77 million, and the project was delayed by 20 days.

2. VO No. 2, Discrepancies between Contract Documents: This was assigned to an increase in the cost of a bill of quantities (BOQ) item, i.e., admixture. At the time of tender, the cost of admixture was low. However, during the construction, the cost of admixture increased abnormally due to high price inflation, which resulted in an additional cost of USD 0.49 million. The project was delayed by 15 work days.

3. VO No. 3, Change of Scope: It was initiated as a result of an additional layer of reinforcing steel in the concrete lining of the 52-km-long power channel of the hydropower project. This variation caused an additional cost of USD 2.18 million and the project was delayed by 30 work days.

4. VO No. 4, Error and Omission in Design: Because of this variation, the railway bridge was increased in height by 2 feet. This resulted in an additional cost of USD 3.64 million, and the project was delayed by 35 work days. A dispute also arose between the employer and the contractor over this variation. 


\section{Case Study No. 2: Hydropower Project, 1000 MW}

Case Study No. 2 examines the dam raising of the Mangla hydropower project, which is located in the vicinity of Mangla district Mirpur Azad Kashmir. The important feature of this project was raising the height of the dam by 30 feet. Its storage capacity was enhanced by $2.88 \mathrm{MAF}$ to allow the generation of $120 \mathrm{MW}$ (644 Gwh/Annum) of additional power. The start and end dates of the project were April 2004 and December 2009, respectively. The project's 43 VOs caused a delay of 282 days, and the VOs selected for study had a time impact of 180 days, or $60 \%$ of the delay. This time impact was the main reason for the selection of these important VOs. The pictorial view of the project is shown in Figure 3.

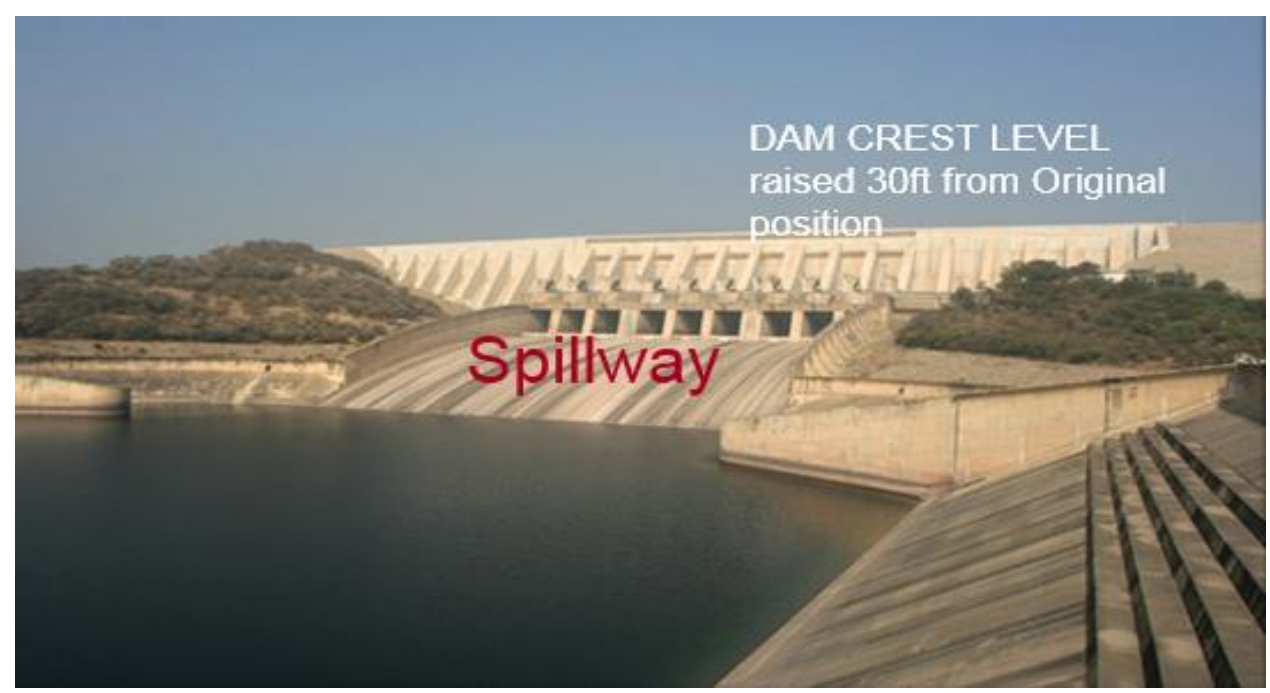

Figure 3. Mangla Raising Hydropower Project (1,000 MW)

The descriptions of the four VOs are as follows:

1. VO No. 1, Change of Scope: It was issued to construct additional stairs to instrument locations and instrument houses at the main dam. To ensure safe access to the extended and new instruments, additional staircases had to be placed at locations other than the six shown on the tender drawings. This variation resulted in an additional cost of USD 0.35 million, and the project was delayed by 40 work days.

2. VO No. 2, Change of Scope: This VO was issued to install a new guard rail at the crest of the dam, which was required for traffic security. It was provided in the construction drawing at tender stage, but the relevant pay item was not provided in the respective $B O Q$. The preparation of the $V O$ was necessitated to allow payment for the work item in accordance with one of the clauses of the contract. This variation resulted in an additional cost of USD 0.34 million, and there was a time impact of 20 work days. 
Hashim Hanif et al.

3. VO No. 3, Change in Design: This VO was issued to construct concrete toe drains of varying sizes at the main dam and intake embankment. At the tender stage, the cross section of a typical drain was given in the drawings. Thus, the engineer had to determine the provision of toe drains during the course of construction of the main dam and intake embankment. At different locations along the extended toe of the dam, toe drains were constructed, which constituted a variation and resulted in an additional cost of USD 0.23 million and a delay of 1 working month.

4. VO No. 4, Error and Omission in Design: It was issued for the underwater placing of a three-foot-thick protective layer of riprap on the toe weight upstream of the intake embankment. The intake toe weight was constructed from sandy gravel from the Jhelum river bed and was composed of rounded to sub-rounded particles of gravel and cobbles. The intake toe weight has a slope facing the tunnel intake. To protect the slope, it was necessary to place a three-foot-thick protective layer of riprap (4- to 12-inch particles) acting as stud against rolling of the rounded riprap particles. This constituted additional work, which was carried out through a VO and resulted in an additional cost of USD 0.72 million and a delay of 70 work days.

\section{Case Study No. 3: Hydropower Project, 969 MW}

The third case study is the Neelum Jhelum Hydroelectric Project (NJHEP) located in the vicinity of Muzaffarabad (AJ\&K). It diverts Neelum river water through a tunnel into the Jhelum River. The intake of the Neelum Jhelum is at Nauseri, $41 \mathrm{~km}$ east of Muzaffarabad. The power house is being constructed at Chatter Kalas, $22 \mathrm{~km}$ south of Muzaffarabad. After passing through the turbines, the water will be released into the Jhelum River approximately $4 \mathrm{~km}$ south of Chatter Kalas. The Neelum Jhelum Hydroelectric Project has an installed capacity of $969 \mathrm{MW}$. The start and end dates of the project are January 2008 and December 2016, respectively. The project's 38 VOs caused delays totalling 730 days and the three out of fours that were selected for the study had a collective impact of 520 days causing $71 \%$ of the project's total delay and VO 4 saved almost a year of work days. The project is to produce 5.15 billion units of electricity annually. 

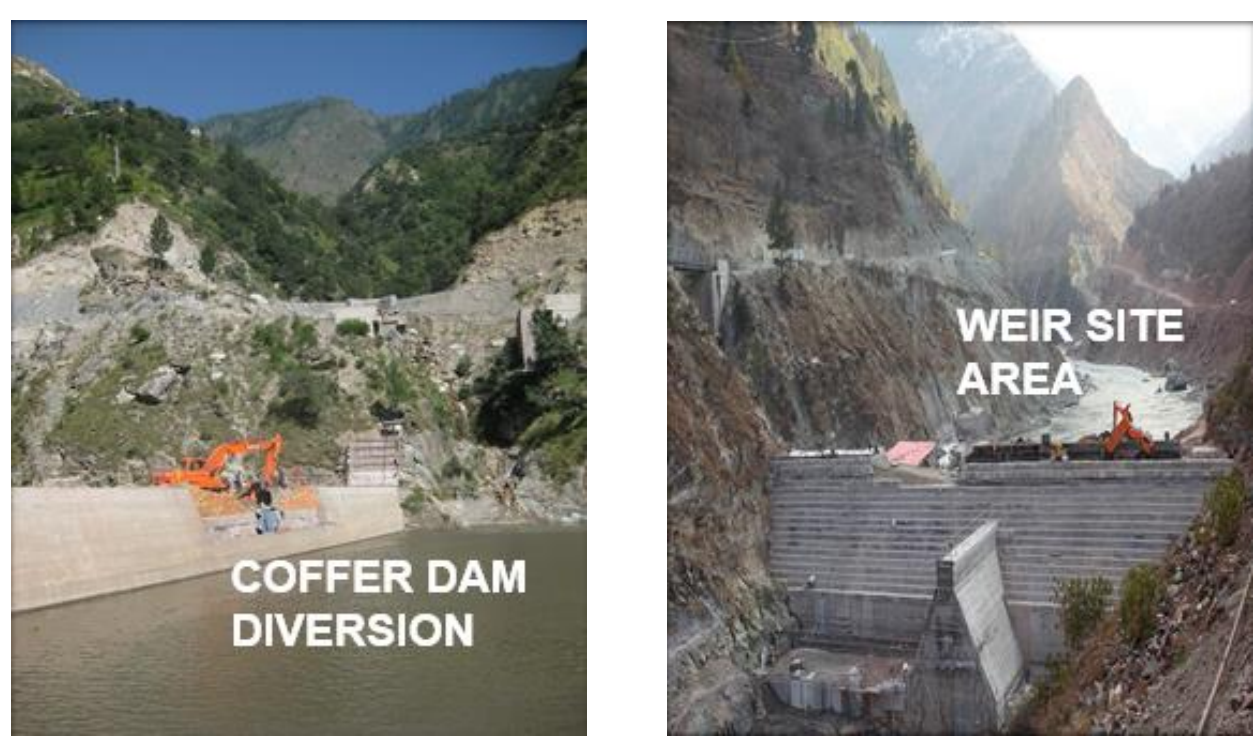

Figure 4. Neelum Jehlum Hydropower Project (969 MW)

During the construction phase of the Neelum Jehlum project, 38 VOs were issued by the consultants before October 2013. The description of four major VOs are as follows:

1. VO No. 1, Change in Design: This VO redesigned the diversion dam, intake and sedimentation basin. Due to the high seismic risks, environmental demands and problems related to land acquisition, it became necessary to make several changes in the existing design. This $V O$ incurred an additional cost of USD 124 million, and the project was delayed by 150 work days.

2. VO No. 2, Change of Scope: This VO was issued to increase hydraulic capacity of the transfer tunnels as per the requirements for the turbines. Concrete lining was introduced instead of shotcrete lining. The diameter of the tunnel was enlarged to overcome the higher friction of shotcrete lining. As a result of this $\mathrm{VO}$, the additional cost to the project was USD 315 million, and the project was delayed by 180 work days.

3. VO No. 3, Error and Omission in Design: It was initiated to include concrete lining of a headrace tunnel. Full face tunnel lining was selected to reduce hydraulic losses and reduce the maintenance and repair costs associated with an unlined tunnel. As a consequence of this variation, the project faced an additional cost of USD 328 million and fell behind schedule by 190 work days.

4. VO No. 4, Unavailability of Equipment: This VO was assigned because of the unavailability of equipment, i.e., tunnel boring machine. To save time on tunnel excavation, the government decided to purchase this machine, which caused an additional cost of USD 480 million to the client but whose use saved almost 365 working days. 
Hashim Hanif et al.

\section{RESULTS AND DISCUSSION}

In all of the aforementioned case studies, VOs had an impact on the project time and costs. Table 3 shows the accumulated impact of time and cost overrun of all VOs of each project.

Table 3. Time and Cost Overrun Due to VOs for All Case Studies

\begin{tabular}{lcccc}
\hline & Case I & Case II & Case III & $\begin{array}{c}\text { Avg. of All } \\
\text { Case Studies }\end{array}$ \\
\hline Total no. of VOs & 46 & 43 & 38 & 42 \\
Time extension due to all VOs (days) & 200 & 282 & 730 & 404 \\
Time impact (\%) & 12.8 & 24.0 & 25.7 & 20 \\
Cost of VOs (million USD) & 12.42 & 4.05 & 1350 & 455 \\
Cost impact (\%) & 4.94 & 1.17 & 89.13 & 31 \\
\hline
\end{tabular}

In all three case studies, only a few key vos were found to cause the majority of the total impact. In the first case study, four of the 46 VOs were considered critical because these four VOs (change in design, discrepancies between documents, change of scope and error and omissions in design) caused a time overrun of 100 days and a cost overrun of USD 7 million, which correspond to $50 \%$ and $56 \%$ of the total time and cost overrun of this project, respectively. In Case Study No. 2, four of the 43 VOs were identified as critical (change of scope, change in design and error and omissions in design) because they led to a time overrun of 180 days and a cost overrun of USD 1.6 million. Moreover, the four VOs represented $63 \%$ and $40 \%$ of the project's total cost and time overrun, respectively. In the third case study, four of the 38 VOs were considered critical. These four VOs (change in design, change of scope, error and omissions in design and unavailability of equipment) caused a time overrun of 520 days and cost overrun of USD 1,247 million, corresponding to $71 \%$ and $94 \%$ of the total impact on cost and time, respectively.

Table 4. Time Overrun (\%) Due to Critical VOs for All Case Studies

\begin{tabular}{lcccc}
\hline & Case I & Case II & Case III & $\begin{array}{c}\text { Avg. of All } \\
\text { Case Studies }\end{array}$ \\
\hline Error and omission in design & 2.25 & 5.94 & 6.71 & 4.9 \\
Change of scope & 1.94 & 5.09 & 6.3 & 4.4 \\
Change in design & 1.29 & 2.54 & 5.30 & 3.0 \\
$\begin{array}{l}\text { Unavailability of equipment } \\
\begin{array}{l}\text { Discrepancies between contract } \\
\text { documents }\end{array}\end{array}$ & -0.96 & - & $(12.8)^{* *}$ & - \\
\hline
\end{tabular}

Notes:

* VOs related to unavailability of equipment or to discrepancies between contract documents only appeared once; thus, no average values are calculated

** The VO caused by unavailability of equipment was introduced to reduce time; thus, it had a negative impact on time overrun 
Table 5. Cost Overrun (\%) Due to Critical VOs for All Case Studies

\begin{tabular}{lcccc}
\hline & Case I & Case II & Case III & $\begin{array}{c}\text { Avg. of All } \\
\text { Case Studies }\end{array}$ \\
\hline Error and omission in design & 1.45 & 0.20 & 21.65 & 7.7 \\
Change of scope & 0.31 & 0.10 & 20.85 & 7.0 \\
Change in design & 0.87 & 0.06 & 5.26 & 2.0 \\
Unavailability of equipment & - & - & 31.5 & $*$ \\
$\begin{array}{l}\text { Discrepancies between contract } \\
\text { documents }\end{array}$ & 0.18 & - & - & $*$ \\
\hline
\end{tabular}

Notes: * VOs related to unavailability of equipment or to discrepancies between contract documents only appeared once; thus, no average values are calculated

By evaluating the causes of the VOs considered in the case studies of the three hydropower projects and comparing their impacts, the most significant causes of VOs were identified. Table 4 presents the impact on time due to critical VOs and their cost impact is presented in Table 5. Tables 4 and 5 contain the five most significant causes with the largest impact on either time or cost of the project in each case study. In all case studies, the following three causes of VOs were found most common: error and omission in design, change of scope and change in design.

\section{COMPARISON OF RESULTS}

The presented case study research was conducted with a basis in the work of Hanif et al. (2014). A quick comparison of the top three VOs in the case study and in the findings of Hanif et al. (2014) is shown in Table 6. In both studies, emission in design, change of scope and change in design are found to be the top three; thus, the findings of the studies match.

Table 6. Comparison of Causes of VOs Revealed by Survey-Based Approach and Case Study Approach

\begin{tabular}{cll}
\hline \multirow{2}{*}{ Rank } & $\begin{array}{l}\text { Causes (Pakistan) (Hanif et al., 2014) } \\
\text { Survey-Based Approach }\end{array}$ & Present Study Case Study Approach \\
\hline 1 & Change of scope & Emission in design \\
2 & Omissions in design & Change of scope \\
3 & Change in design & Change in design \\
\hline
\end{tabular}


Hashim Hanif et al.

Table 7. Comparison of Causes of VOs Revealed by Different Studies

\begin{tabular}{|c|c|c|c|c|}
\hline Rank & $\begin{array}{l}\text { Causes (Pakistan) } \\
\text { (Hanif et al., 2014) }\end{array}$ & $\begin{array}{l}\text { Causes (Malaysia) } \\
\text { (Mohammad et al., } \\
\text { 2010) }\end{array}$ & $\begin{array}{l}\text { Causes (Iran) } \\
\text { (Ismail et al., 2012) }\end{array}$ & $\begin{array}{c}\text { Causes (Oman) } \\
\text { (Alnuaimi et al., } \\
\text { 2010) }\end{array}$ \\
\hline 1 & Change of scope & $\begin{array}{l}\text { Change of plan by } \\
\text { owner }\end{array}$ & Change of plan & $\begin{array}{l}\text { Owners instruct } \\
\text { additional work }\end{array}$ \\
\hline 2 & $\begin{array}{l}\text { Omissions in } \\
\text { design }\end{array}$ & $\begin{array}{l}\text { Substitution of } \\
\text { materials }\end{array}$ & $\begin{array}{l}\text { Errors and omissions } \\
\text { in design }\end{array}$ & $\begin{array}{l}\text { Owners instruct } \\
\text { changes in } \\
\text { design }\end{array}$ \\
\hline 3 & Change in design & $\begin{array}{l}\text { Change in design } \\
\text { by consultant }\end{array}$ & $\begin{array}{l}\text { Differing site } \\
\text { conditions }\end{array}$ & $\begin{array}{l}\text { Non-availability } \\
\text { of manuals and } \\
\text { procedures }\end{array}$ \\
\hline 4 & $\begin{array}{l}\text { Change of } \\
\text { project schedule }\end{array}$ & $\begin{array}{l}\text { Errors and omissions } \\
\text { in design }\end{array}$ & Weather conditions & $\begin{array}{l}\text { Non-availability } \\
\text { of license to } \\
\text { maintain quality } \\
\text { of consultancy } \\
\text { service }\end{array}$ \\
\hline 5 & $\begin{array}{l}\text { Conflicts between } \\
\text { contract } \\
\text { documents }\end{array}$ & $\begin{array}{l}\text { Scope of work for } \\
\text { the contractor }\end{array}$ & $\begin{array}{l}\text { Employer's financial } \\
\text { problems }\end{array}$ & $\begin{array}{l}\text { Poor } \\
\text { communication } \\
\text { between } \\
\text { government } \\
\text { and owner }\end{array}$ \\
\hline
\end{tabular}

Moreover, the top causes of VOs identified are similar to the findings from previous VO studies. Table 7 shows the top five causes of VOs from research studies conducted in Oman, Malaysia, Iran and Pakistan. Change of scope, omissions in design and changes in design are found to be top causes in all studies (with varying wording). Thus, this study's results support and strengthen the findings of previous research.

Other important causes are the unavailability of equipment, change of project schedule, substitution of materials, non-availability of manuals and procedures, non-availability of license to maintain quality of consultancy service and weather conditions.

\section{CONCLUSIONS AND RECOMMENDATIONS}

This paper presented a detailed case study based on analysis of the impacts that VOs have on the time and cost of hydropower projects in Pakistan. The following important conclusions/findings can be drawn from this research.

VOs occurred in all three mega hydropower projects followed in the study. Their frequency varied between 38 and 46, with an average of 42 registered occurrences.

1. The causes of VOs with the most significant impacts on time and cost of construction of hydropower projects in Pakistan were: (a) error and omissions in design, (b) change of scope, (c) change in design, (d) 
unavailability of equipment and (e) discrepancies between contract documents.

2. Case studies capturing the actual time and cost impacts revealed that a few VOs can comprise the majority of the total impact on cost and time of the project.

3. In all three case studies, individual VOs' impact on time varied between $12.8 \%$ and $25.7 \%$, corresponding to an average time overrun of $20 \%$ with respect to all the VOs occurring throughout the project lifetime.

4. In relation to the cost impact, the VOs had an impact between $4.94 \%$ and $89.13 \%$, corresponding to an average cost overrun of $31 \%$ with respect to all the VOs occurring throughout the project lifetime.

5. The average impacts of the three most critical causes were calculated: error and omissions in design (time overrun: $4.9 \%$ and cost overrun: $7.7 \%$ ), change of scope by employer (time overrun: $4.4 \%$ and cost overrun: $7.0 \%$ ) and change in design (time overrun: $3.0 \%$, and cost overrun: $2.0 \%$ ).

Based on the findings of this research study, the key recommendations to reduce the frequency and impact of VOs in future construction projects are as follows:

1. The most critical cause, i.e., errors and omissions in design, can be reduced by engaging appropriate design consultants who have participated in the completion of similar construction projects. Employment of a permanent and well-settled team member can lead to successful project completion and create an environment of mutual understanding among the project's key stakeholders.

2. With regard to the second most critical cause of VOs, i.e. change of scope, it is recommended that proper and detailed feasibility study, project design and modelling techniques be carried out before finalisation of the scope of work. The working personnel should have worked previously on similar hydropower projects, and lessons learnt should be adopted to reduce scope creep.

3. Keeping the remaining three critical causes of VOs in mind, it is recommended that consultants not transfer well-settled design team members from their respective offices to avoid hampering project design activities and that the client ensure, at the stage of bidding, that the contractor has all of the equipment needed to construct the project. A proper review of the method statement, a resource-loaded schedule which clearly defines the role and responsibilities of labour and equipment and anticipated progress curves of the project can prevent these causes of VOs. Moreover, a proper constructability analysis by a panel of experts before the start of the project can reduce discrepancies in the contract documents. 


\section{REFERENCES}

Al-Jishi, S. and Al-Marzoug, H. (2008). Change orders in construction projects in Saudi-Arabia. Construction Engineering and Management Department Term Paper (CEM-520 Term Paper). Saudi Arabia: King Fahd University of Petroleum and Minerals.

Al-Momani, A.H. (2000). Construction delay: A quantitative analysis. International Journal of Project Management, 18(1): 51-59. http://dx.doi.org/10.1016/ S0263-7863(98)00060-X

Alnuaimi, A., Taha, R., Al Mohsin, M. and Al-Harthi, A. (2010). Causes, effects, benefits, and remedies of change orders on public construction projects in Oman. Journal of Construction Engineering and Management, 136(5): 615622.http://dx.doi.org/10.1061/(ASCE)CO.1943-7862.0000154.

Arain, F.M., Assaf, S. and Low, S.P. (2004). Causes of discrepancies between design and construction. Architectural Science Review, 47(3): 237-249. http://dx.doi.org/10.1080/00038628.2000.9697530.

Arain, F.M. and Low, S.P. (2005). The nature and frequency of occurence of variation orders for educational building projects in Singapore. International Journal of Construction Management, 5(2): 79-91. http://dx.doi.org/ 10.1080/15623599.2005.10773076.

Bower, D. (2000). A systematic approach to the evaluation of indirect costs of contract variations. Construction Management and Economics, 18(3): 263268. http://dx.doi.org/10.1080/014461900370636.

Construction Industry Institute (CII). (1990). The Impact of Changes on Construction Cost and Schedule. Austin, TX: Cll, University of Texas at Austin.

Enshassi, A., Arain, F. and Al-Raee, S. (2010). Causes of variation orders in construction projects in the Gaza Strip. Journal of Civil Engineering and Management, 16(4): 540-541. http://dx.doi.org/10.3846/jcem.2010.60.

Fisk, E.R. (1997). Construction Project Administration. 5th Ed. Upper Saddle River, NJ: Prentice-Hall.

González, V., Alarcón, L.F., Maturana, S., Mundaca, F. and Bustamante, J. (2010). Improving planning reliability and project performance using the reliable commitment model. Journal of Construction Engineering and Management, 136(10): 1129-1 139. http://dx.doi.org/10.1061/(ASCE)CO.1943-7862.0000215.

Goodacre, P.E. and Hunter, A.A. (1990). Delays and Disruptions in Construction: Ascertaining the Cost. Berkshire, UK: Chartered Institute of Building.

Hanif, H., Khurshid, M.B., Malik, S. and Nauman, S. (2014). Causes of variation orders in construction of hydropower projects of Pakistan. Paper presented at the International Conference on Management and Engineering (CME 2014). Shanghai, China, 24-25 May.

Hanna, A.S, Calmic, P.E. and Peterson, R. (2002). Quantitative definition of projects impacted by change orders. Journal of Construction Engineering and Management, 128(1): 57-64. http://dx.doi.org/10.1061/(ASCE)07339364(2002) 128:1 (57).

Haseeb, M., Lu, X., Aneesa, B., Maloof-ud-Dyian and Rabbani, W. (2011) Causes and effects of delays in large construction projects in Pakistan. Kuwait Chapter of Arabian Journal of Business and Management Review, 1 (4): 1842. 
Ibbs, C.W. (1997). Change's impact on construction productivity. Journal of Construction Engineering and Management, 123(1): 89-97.

ljaola, I.A. and lyagba, R.O. (2012). A comparative study of causes of change orders in public construction project in Nigeria and Oman. Journal of Emerging Trends in Economics and Management Sciences, 3(5): 495-501.

Ismail, A., Pourrostam, T., Soleymanzadeh, A. and Ghouyounchizad, M. (2012). Factors causing variation orders and their effects in roadway construction projects. Research Journal of Applied Sciences, Engineering and Technology, 4(23): 4969-4972.

Lindhard, S. (2014). Understanding the effect of variation in a production system. Journal of Construction Engineering and Management, 140(11): 04014051. http://dx.doi.org/10.1061/(ASCE)CO.1943-7862.0000887.

Lindhard, S. and Wandahl, S. (2014). Exploration of the reasons for delays in construction. International Journal of Construction Management, 14(1): 3644. http://dx.doi.org/10.1080/15623599.2013.875267.

Love, P.E.D. (2002). Influence of project type and procurement method on rework costs in building construction projects. Journal of Construction Engineering and Management, 128(1): 18-29. http://dx.doi.org/10.1061/(ASCE)07339364(2002) 128:1 (18)

Mohammad, N., Che Ani, A.I., Rakmat, R.A.O.K. and Yusof, M.A. (2010). Investigation on the causes of variation orders in the construction of building project: A study in the state of Selangor, Malaysia. Journal of Building Performance, 1 (1): 73-82.

Nunnally, J. (1978). Psychometric Theory. New York: McGraw-Hill Book Company.

O'Brien, J.J. (1998). Construction Change Orders. New York: McGraw-Hill Book Company.

Ssegawa, J.K., Mfolwe, K.M., Makuke, B. and Kutua, B. (2002). Construction variations: A scourge or a necessity? Proceedings: First International Conference of CIB W107. Cape Town, South Africa, 11-13 November.

Sun, M. and Meng, X. (2009). Taxonomy for change causes and effects in construction projects. International Journal of Project Management, 27(6): 560-572. http://dx.doi.org/10.1016/j.jproman.2008.10.005.

Thomas, H.R., Horman, M.J., De Souza, U.E.L. and Zavřski, I. (2002). Reducing variability to improve performance as a lean construction principle. Journal of Construction Engineering and Management, 128(2): 144-154. http://dx.doi.org/10.1061/(ASCE)0733-9364(2002) 128:2(144).

Yin, R.K. (2003). Case Study Research, Design and Methods. 3rd Ed. Newbury Park, CA: Sage Publications. 